九州大学学術情報リポジトリ

Kyushu University Institutional Repository

Bees of the Mariana Islands, Micronesia, collected by the Expedition of the Natural History Museum \& Institute, Chi ba (Hymenoptera, Apoidea)

Tadauchi, 0samu

https://doi.org/10.5109/2578

出版情報: ESAKIA. 34，pp.215-225，1994-03-24. Entomological Laboratory，Faculty of Agriculture, Kyushu University バージョン :

権利関係 : 


\title{
Bees of the Mariana Islands, Micronesia, collected by the Expedition of the Natural History Museum \& Institute, Chi ba (Hymenoptera, Apoidea)
}

\author{
Osamu TADAUCHI \\ Entomological Laboratory, Faculty of Agriculture, \\ Kyushu University, Fukuoka, 812 Japan
}

\begin{abstract}
Seven species of bees are recorded, based on 146 specimens mainly collected on the Northern Mariana Islands, Micronesia, by the Expedition of the Natural History Museum \& Institute, Chiba, in 1992. One new species, Lasioglossum (Evylaeus) miyanoi is described from Rota Is. A total of 11 ncw records of bees arc reported from 7 islands. The Southern Marianas have a larger endemic bee fauna, while the Northern Marianas appear to have a moderate fauna with 6 bees including 2 endemic species. The fauna of the Northern Marianas is strongly related to that of the Southern Marianas and dishannonic in components;
\end{abstract}

\section{INTRODUCTION}

This paper deals with Apoidea collected by Dr. Sinya Miyano in the Northern Mariana Expedition of the Natural History Museum \& Institute, Chiba, in 1992. The Mariana Islands are divided into two groups, i.e., the Northern Islands from Maug to Anatahan, and the Southern Islands from Saipan to Guam (Fig. 1). The collection consists of two separate groups, 134 specimens from the Northern Islands (Maug, Agrihan, Pagan, Alamagan, Guguan and Anatahan, from north to south) and 12 specimens from the Southern Islands (Saipan and Rota). The specimens are classified into 7 species belonging to 6 genera in 4 families including one new species from Rota Island and 11 new records from 7 islands.

With respect to faunistic papers on Apoidea of Micronesia except for scattered descriptions, Fullaway (1913) presented the first report from Guam Island including 5 species. Yasumatsu (1935, 1939a, 1939b, 1942) and Cockerell (1942) reported bees of Micronesia based on the material col-

1) Contribution from the Entomological Laboratory, Faculty of Agriculture, Kyushu University, Fukuoka (Ser. 4, No. 64). 
lected by the Esaki expeditions carried out from 1936 to 1940.

em, with 4 in common).

The present collection helps correct the deficiency of faunistic information on the Northern Islands with the first bee records from Maug, Alamagan, Guguan and Anatahan Islands. Six species are enumerated from the Northern Marianas and 14 from the Southern Marianas based on the present survey. New records of bees from each island are shown by asterisks in the following report.

\section{SYSTEMATICS}

\section{Family Halictidae}

1. Homalictus vexator (Krombein, 1950) (Fig. 3A)

Halictus (Homalictus) vexator Krombein, 1950. Proc. Hawaii. Entomol. Soc. 14: 117 [female; Agrihan Is.; type in U. S. National Museum].

Homalictus vexator: Michener, 1965. Bull. Amer. Mus. Nat. Hist., 130: 181.

Krombein (1950) listed seven species of Homalictus from Micronesia. Among them one is from the Northern Marianas, 3 from the Southern Marianas and 3 from the Carolines. According to the data, this species is endemic to the Northern Marianas and is common in the islands.

Specimens examined: 1.5 females, Guguan I., N. Mariana Is., 17. v. 1992 (S. Miyano); 24 females, same data as above except 18. v. 1992; 1 female, Pagan I., N. Mariana Is., 27. v. 1992 (S. Miyano); 5 females, Agrihan I., N. Mariana Is., 28. v. 1992 (S. Miyano); 37 females, same data as above except 31. v. 1992.

Distribution: Mariana Is. (Agrihan I., *Pagan I., *Guguan I.)

\section{Lasioglossum (Evylaeus) miyanoi Tadaucbi, new species (Fig. 2A-D)}

Female. Body length 5.0-5.6 mm, wing including tegula 4.2-4.4 mm.

Coloration. Black except as follows: mandible with apical third reddish brown; flagellar segments 2-10 beneath and tegula pale brownish; distitarsi and claws brownish;' wings transparent with veins and stigma pale brown; metasomal terga posteriorly pale brownish.

Pilosity. Hairs whitish, partly yellow-tinted; clypeus with hairs long, decumbent, simple to poorly plumose; submarginal bristles fine; paraocular area with hairs sub-appressed, distinctly plumose; vertex with yellow-tinted hairs, relatively long, erect, sparse and poorly plumose; pronoturn with dense, erect tomentum; mesoscutum with hairs erect, very short, poorly plumose, surface clearly visible; mesoscutellum similar but hairs longer; metanotum with dense tomentum, with long, erect and plumose hairs posteriorly and laterally, covering surface completely; mesopleuron with moderately dense, erect and plumose hairs, shorter above, longer below; tegula with sparse, semierect hairs anteriorly, glabrous distally; metasomal tergum 1 (T1) with conspicuous basolateral 


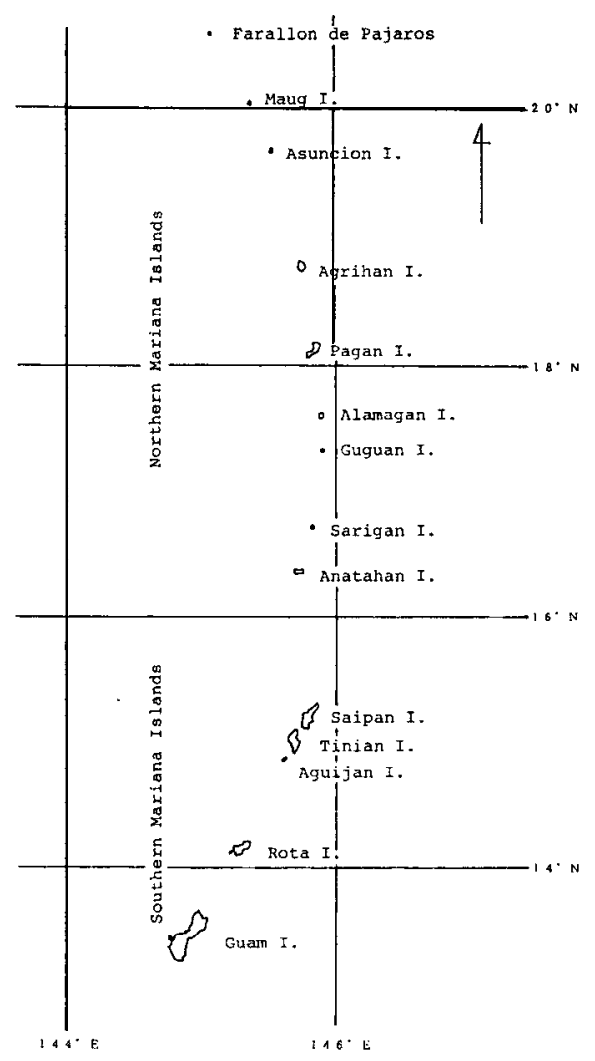

Fig. 1. A map of Mariana Islands.

Table 1. A summary of bee fauna in the Bonin Is. and Micronesia.

\begin{tabular}{lcccc}
\hline Islands & Total sp. no & Endemics & Endemism(\%) & Introduced \\
\hline Bonin Is. & 8 & 7 & 87.5 & 1 \\
N. Mariana Is. & 6 & 2 & 33.3 & 1 \\
S. Mariana Is. & 14 & 8 & 57.1 & 2 \\
Caroline Is. & 16 & 9 & 56.3 & 1 \\
Palau I. & 10 & 6 & 60.0 & 1 \\
Yap I. & 7 & 5 & 71.4 & 0 \\
Truk I. & 6 & 2 & 33.3 & 0 \\
Ponape I. & 5 & 2 & 40.0 & 1 \\
Kusaie I. & 4 & 1 & 25.0 & 0 \\
Marshall Is. & 2 & 0 & 0.0 & 0 \\
\hline
\end{tabular}


tomental patch and with long, erect hairs medially poorly plumose, and laterally distinctly plumose; hairs on disc medially sparse, simple and short; marginal area medially glabrous, submedially and laterally with sparse, simple, sub-appressed hairs; T2 anteriorly with rather conspicuous tomental band, not interrupted medially, broader laterally; disc medially with sparse, simple hairs, and denser, suberect hairs laterally; T3 and T4 with basal patches broad and not interrupted medially, hairs on disc much longer, stouter and denser; sternal scopa sparse, partly plumouse.

Structure. Head oval, slightly wider than long $(1.04: 1.0)$, vertex convex; inner orbit distinctly convergent below; MOD (maximum interorbital distance) : UOD (upper interorbital D) : LOD (lower interorbital D) $=1.0: 0.87: 0.73$; POD (postocellar D):OOD (ocellocular D): OCD (ocelloccipital D) $=1.0: 0.76: 0.59$; vertex shiny and smooth with shallow, fine $(15-20 \mu \mathrm{m})$ punctures $(=\mathrm{PP})$, interspaces $(=\mathrm{IS})$ irregular, $\phi \mathrm{P}>\mathrm{IS}$; ocellocular area flat, smooth and shiny, with fine PP $(15 \mu)$, $\phi \mathrm{P}<\mathrm{IS}$; frons flat with microareolation $(\phi 20-25 \mu)$; paraocular area with PP of $20-25 \mu$ (IS OS-1.0 P), sparser downward, and IS smoother and more shiny; supraclypeal area moderately convex, with PP $(20 \mu)$, shallow, sparse medially, denser laterally $(\mathrm{IS}<\mathrm{P})$; clypeus below depressed; clypeus above with shallow, ill-defined PP $(\phi 15-30 \mu, \mathrm{IS}=1-1.5 \mathrm{P})$, below with irregular, obscure, elongate PP $(\phi$ 40-60 $\mu$ ); CPL (clypeus length) : CAL (clypealveolar D=D between level of lower rims of antennal sockets and lower margin of clypeus): APL (apical part of clypeal L=L of part exceeding lower orbital line) $=1.0: 1.77: 0.42$.

Mesoscutum with fine (15-20 $)$, weak PP, IS finely tessellate and dull, 1.0-2.0 $\phi$; mesoscutellum mildly convex, as on mesoscutum with shiny, smooth and impunctate space lateromedially; mesopleuron with irregular, coarse, transverse rugose. Propodeal dorsum with strong, longitudinal ridges, partially branching, covering whole area; SCL (mesoscutellum length): MNL (metanotum L): PDL (propodeal dorsum L) $=1.0: 0.63: 0.79$; lateral and apical margin of propodeal dorsum delimited by distinct carina; legs of the usual Lasioglossum type; basitibial plate elongate, with apex roundly pointed; inner hind tibial spur with 3 moderately long teeth.

Metasomal terga oval; T1 both declivity and disc, shiny and transversely, very week lincolate with sparse and fine PP, denser and coarser laterally; tergum 2-4 nearly smooth and shiny anteriorly and transversely lineolate and dully shining posteriorly, with dense, fine PP ( $\phi 15 \mu$ IS 1-2 PP); marginal area weakly depressed.

Male. Unknown.

Type material: Holotype female, Rota I., S. Mariana Is., 13. vi. 1992 (S. Miyano). Paratypcs, 2 females, same data as holotype.

Type depository: The holotype and one paratypc are prescrved in the Natural History Museum \& Institute, Chiba, and one paratype is in the Entomological Laboratory, Faculty of Agriculture, Kyushu University.

Distribution: Mariana Is. (Rota I.)

\section{Family Megachilidae}

\section{Lithurge (Lithurge) scabrosus (Smith, 1859) (Fig. 3B)}




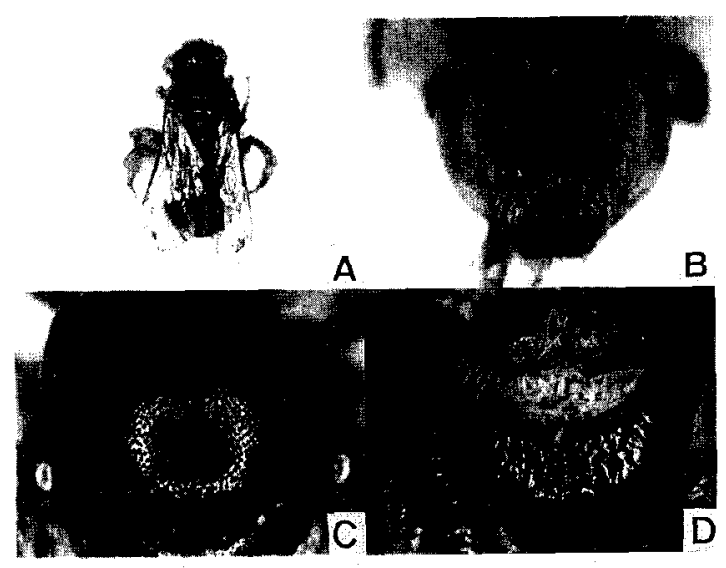

Fig. 2.Lasioglossum (Evylaeus) miyanoi, n. sp., A: dorsal view; B: head in frontal view; C: mesoscutum in dorsal view; D: metanotum and propodeum in dorsal view.

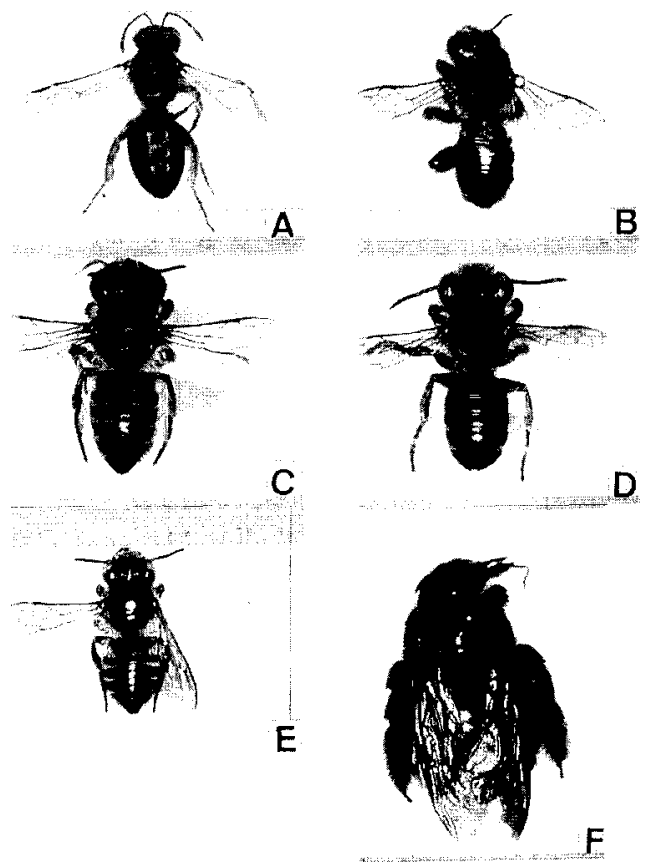

Fig. 3. Dorsal view of the bees, A: Homalictus vexator, female (body length=BL $5.8 \mathrm{~mm}$ ); B: Lithurge scabrosus, male (BL $12.7 \mathrm{~mm}$ ), C: Megachile fullawayi, female (BL 9.4mm); D: M. fullawayi, male (BL 9.1mm); E: Megachile laticeps, female (BL 11.4mm); F: Xylocopa brasilianorum varipuncta (BL 20.6mm). 
Megachile scabrosus Smith, 1859. J. Proc. Linn. Soc., 3: 134 [female; Aru Is.; type in Hope Museum, Oxford Univ.].'

Lithurgus albo-fimbriatus Sichel, 1867. Reise Novara, Zool., 2: 1.51 [female; Tahiti].

Lithurgus sp. Fullaway, 1913. Proc. Hawaii. Entomol. Soc., 2: 282 [Guam].

Lifhurgus guamensis Cockerell, 1914. Ann. Mag. Nat. Hist. (8)14: 1 [female; Guam]; Yasumatsu, 1939. Tenthredo, 2: 333 [female \& male; Saipan, Kusaie, Ponape, Truk, Palaus]; Cockerell, 1942. B. P. Bishop Mus. Bull., 172: 189.

Lifhurgus albofimbriatus froggatti: Cockerell, 1914. Ann. Mag. Nat. Hist. (8) 14: 469 [female; New Hebrides].

Lifhurgus scabrosus froggatti Cockerell, 1929. Rec. Austral. Mus., 17: 233.

Lifhurgus scabrosus: Cockerell, 1939. Occas. Papers B. P. Bishop Mus., 15: 64 [Yap, Palaus, Ponape].

Lifhurgus (Lithurgus) scubrosus : Krombein, 19.50. Proc. Hawaii. Entomol. Soc., 14: 120 [Marianas, Carolines]

This species is widely distributed in Polynesia, Micronesia and Hawaii.

Specimens examined: 4 males, Guguan I., N. Mariana Is., 17. v. 1992 (S. Miyano); 1 male, same data as above except 18. v. 1992 (S. Miyano); 3 males, East I. of Maug I. of N. Mariana Is., 2. vi. 1992 (S. Miyano).

Distribution: Mariana Is. $\left({ }^{*}\right.$ Maug I., Agrihan I., *Guguan I., Saipan I., Tinian I., Guam I.), Caroline Is.(Palau I., Yap I., Truk I., Ponape I., Kusaie Atoll), New Hebrides, Fiji, Samoa, Tahiti, Rarotonga, Society Is., Marquesas and Hawaii.

4. Megachile (Euricharaea) fullawayi Cockerell, 1914 (Fig. 3C-D)

Meguchile sp. Fullaway, 1913. Proc. Hawaii. Ent. Soc., 2: 282 [Guam].

Meguchile fullawayi Cockerell, 1914. Ann. Mag. nat. Hist. (8)14: 2 [female \& malc; Guam; type in U.S. National Museum]; Yasumatsu, 1939. Tenthredo, 2: 336 [Kusaie, Jaluit]; Yasumatsu, 1942. Tenthredo, 3: 335 [Pagan]; Cockerell, 1942. B. P. Bishop Mus. Bull., 172: 189.

Megachile (Euricharaea) fullawayi: Krombein. 1950, Proc. Hawaii. Entomol. Soc., 14: 126 [Marianas, Marshalls, Carolines].

This species is widely recorded in Micronesia including Marianas, Carolines and Marshalls.

Specimens examined: '1 female, Anatahan I., N. Mariana Is., 11. v. 1992 (S. Miyano); 1 male, Agrihan I., N. Mariana Is., 28. v. 1992 (S. Miyano); 2 females and 1 male, same data as above except 30. v. 1992; 1 male, same data as above except 31. v. 1992; 3 females and 1 male, East I. of Maug I., N. Mariana Is., 2. vi. 1992 (S. Miyano); 1 female, same data as above except 4. vi. 1992; 1 female, North I. of Maug I., N. Mariana Is., 3. vi. 1992 (S. Miyano).

Distribution: Mariana Is.( ${ }^{*}$ Maug I., *Agrihan I., Pagan I., *Anatahan I., Guam I.), Caroline Is.(Yap I., Kusaie Atoll, Nukuro Atoll, Kapingamarangi Atoll) and Marshall Is.(Eniwetok Atoll, Kwajalein Atoll., Jaluit Atoll, Majuro Atoll).

5. Meguchile laticeps Smith, 1853 (Fig. 3E)

Meguchile laticeps Smith, 1853. Cat. Hym. Brit. Mus., 1: 183 [male; Philippines; type in British 
Museum]; Cockerell, 1939. Occas. Papers B. P. Bishop Mus., 1.5: 63 [female \& male; Carolines]; Yasumatsu, 1942. Tenthredo, 3: 337; Cockerell, 1942. B. P. Bishop Mus. Bull., 172: 188 [Guam]; Krombein, 1950. Proc. Hawaii. Entomol. Soc., 14: 127 [Marianas, Carolines]. Megachile caecina Cameron, 1903. J. Str. Br. Roy. Asia. Soc., (39): 173 [female; Trusan]. Megachile borneana Cameron, 1903. J. Str. Br. Roy. Asia. Soc., (39): 174 [female; Kuching]. Meguchile gadara Cameron, 1903. J. Str. Br. Roy. Asia. Soc., (39): 176 [male; Kuching]. Meguchile robii Ashmead, 1904. Proc. U. S. Nat. Mus., 28: 128 [female; Manila]. Meguchile semperi Friese, 1905. Ztschr. Hym. Dipt., 5: 17 [female; Palaus]; Yasumatsu, 1935, Mushi, 8: 95 [Tinian]; Cockerell, 1939. Occas. Papers B. P. Bishop Mus., 15: 63; Yasumatsu, 1939. Tenthredo, 2: 335 [Marianas, Carolines, Palaus].

Meguchile varidens Cameron, 1905. J. Str. Br. Roy. Asia Soc.,(44): 166 [male; Kuching]. Meguchile metallescens Cockerell, 1918. Phil. J. Sci., 13: 135 [female; Luzon].

Meguchile mcgregori Cockerell, 1918. Phil. J. Sci., 13: 140 [male; Luzon].

This species is widely distributed in Marianas and Carolines in Micronesia. Krombein (1950) pointed out that some variation was found in the amount of black hairs in the scopa of the fifth sternum. AU the specimens collected by the present expedition show normal state, i.e., having black scopa only laterally on the segment.

Specimens examined: 2 females, Alamagan I., N. Mariana Is., 9. v. 1992 (S. Miyano); 3 females, same data as above except 19. v. 1992; 3 females and 2 males, Anatahan I., N. Mariana Is., 11. v. 1992 (S. Miyano); 1 male, Pagan I., N. Mariana Is., 24. v. (S. Miyano); 3 females and 2 males, Agrihan I., N. Mariana Is., 28. v. 1992 (S. Miyano); 3 females and 1 male, same data as above except 29. v. 1992; 6 females, same data as above except 30. v. 1992; 1 female and 1 male, same data as above except 31. v. 1992.

Distribution: Mariana Is. (Agrihan I., Pagan I., *Alamagan I., *Anatahan I., Saipan I., Tinian I., Rota I., Guam I.), Caroline Is.(Palau I., Yap I., Truk I., Ponape I., Kusaie Atoll), Philippines and Borneo.

\section{Family Anthophoridae}

6. Xylocopa bmsilianorum varipuncta Patton, 1879 (Fig. 3F)

Xylocopa varipuncta Patton, 1879. Canad. Ent., 11: 60 [female; Arizona].

Xylocopu brusiliunorum varipuncta: Ackerman, 1916. J. N. Y.Ent. Soc., 24: 226; Krombein, 1950.

Proc. Hawaii. Entomol.Soc., 14: 133 [Saipan, Guam].

Krombein (1950) noted that this species was introduced to the Marianas from Hawaii in the 1940 's.

Specimens examined: 3 females, Garapan, Saipan I., S. Mariana Is. 21. v. 1992 (S. Miyano).

Distribution: Mariana Is. (Saipan I., Guam I.), Hawaii and North America. 
7. Apis mellifera Linnaeus, 1758

Apis mellifera Linnaeus, 1758. Syst. Nat., 10th Edit., p. 576; Fullaway, 1913. Proc. Hawaii. Ent. Soc., 2: 282 [Guam]; Esaki, 1936. Mushi, 9: 44 [Koror, Palaus]; Cockerell, 1942. B. P. Bishop Mus. Bull., 172: 188 [Guam]; Townes, 1947. Rpt. 14, U.S. Comm. Co. Surv. Micronesia, p. 51 [Ponape, Palaus, southern Marianas]; Krombein, 1950. Proc. Hawaii. Entomol. Soc., 14: 135 [Marianas, Carolines].

Fullaway (1913) noted that this species was introduced to Guam from Hawaii in 1907.

Specimens examined: 1 worker, Mt. Tapotchao, Saipan I., S. Mariana Is., 7. v. 1992 (S. Miyano); 1 worker, Garapan, Saipan I., S. Mariana Is., 21. v. 1992 (S. Miyano); 2 workers, Pagan I., N. Mariana Is., 24. v. 1992 (S. Miyano); 4 workers, Rota I., S. Mariana Is., 13. vi. 1992 (S. Miyano).

Distribution (only cited from Micronesia): Mariana Is. (*Pagan I., Saipan I., *Rota I., Guam I.), Caroline Is. (Palau I., Ponape I.).

\section{CHARACTERISTIC OF BEE FAUNA OF THE NORTHERN MARIANA ISLANDS}

Table 1 shows a summary of bee fauna in the Bonin Islands and Micronesia based on Krombein (1955) and the present data. The Southern Mariana Islands appear to have the richest fauna (14 species) and the highest number of endemic species ( 8 species), followed by Palau Island (10 and 6 species) in Carolines. It also shows the Bonin Islands have the highest endemism (87.5\%) although the fauna is not very rich. As generally reported in insects of the Pacific Islands, the table shows the numbers of species and endemics in decreasing order from west to east in Carolines in the Pacific Ocean. It also indicates a drop of the species number and endemics between the Bonin Islands and the Southern Mariana Islands.

Table 2 shows distribution of bees for each island in the Marianas with total numbers in the Carolines and Marshalls. The percentage of endemism in the bees (66.7\%) in Micronesia is much higher than those in other insects, (e.g., wasps, 44.2\%, Krombein, 1950; Dermaptera, 40.0\%, Brindle, 1972). The Southern Marianas have 14 species including 7 endemics, while the Northern Marianas have 6 including 2 endemics. Gressitt et al. (1961) stated "Going northward from Guam and southward from the Bonin Islands there is an impoverishment, in the Volcano and Northern Mariana Islands, related to greater distance from continental islands as well as to smaller size and yonger nature of the islands". The present expedition supplied some lacks of faunal information in the Northern Marianas, and revealed them to have a moderate bee fauna including a few endemics.

Figure 4 shows proportions of the numbers of components for Northern (A) and Southern (B) Mariana Islands. The feature of bee fauna in the Northern Islands is poor in endemics. Five of six species recorded from the Northern Islands are in common with those from the Southern Islands and no common species with the Bonin Islands except for Apis mellifera. Fennah (1956) noted the discontinuity between the Marianas and the Bonins in discussing Micronesian Fulgoroidea (Homoptera). The bee fauna gives support to his conclusion. Table 3 shows a matrix of Nomura-Shimpson's coefficients (NSC) among the 10 islands shown in Table 1. The coefficient is calculated for 
Table 2. Distribution of bees for each island in the Mariana Islands with total numbers of Carolines and Marshalls. Codes for islands are as follows. Mg: Maug I.; As: Asuncion I.; Ag: Agrihan I.; P: Pagan I.; Al: Alamagan I.; Gg: Guguan I.; An: Anatahan I.; S: Saipan I.; T: Tinian I.; R: Rota I.; Gm: Guam I.; C: Caroline Is.; Ms: Marshall Is.

$\begin{array}{lllllllllllllll}\text { Species name } & \mathrm{Mg} & \mathrm{As} & \mathrm{Ag} & \mathrm{P} & \mathrm{Al} & \mathrm{Gg} & \mathrm{An} & \mathrm{S} & \mathrm{T} & \mathrm{R} & \mathrm{Gm} & \mathrm{C} & \mathrm{Ms}\end{array}$

\section{Colletidae}

Hylaeus guatnensis

H. rotensis

H. yapensis

H. hirticaudus

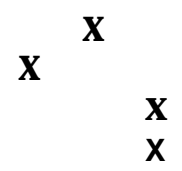

Halictidae

Halictus yapensis

Homalictus palaonicus

H. nummatus

H. auriger

H. swezeyi

H. rotaensis

H. saffordi

H. vexator

Lasioglossum miyanoi

Megachilidae

Lithurge scabrosus, $\mathrm{X} \quad \mathrm{X}$

Heriades paganensis

H. plumosa

Megachile umbripennis

M. fullawayi

M. laticeps

$M$. palaonica

M. diligens hedleyi

Anthophoridae

Ceratina mariannensis

C. palauensis

Xylocopa brasilianorum varipuncta

Apidae

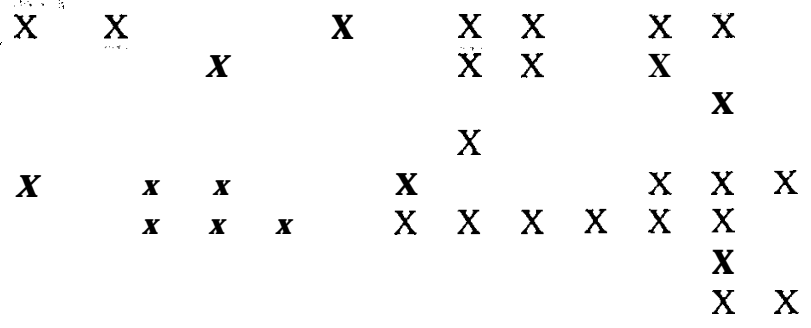

Trigona fuscobalteata

$T$. iridipennis

Apis mellifera

x $\quad$ X

$\mathbf{X}$
$\mathbf{X}$
$\mathbf{X}$
$\mathbf{X}$

$\begin{array}{llll}X & & X & X \\ & X & X & \end{array}$

$\mathrm{X}$

Total sp. no

X $\quad \mathrm{X}$

$x$

X $\quad \mathrm{X}$ 
Table 3. A matrix of Nomura-Shimpson's coefficients among ten islands in Micronesia.

\begin{tabular}{lccccccccccc}
\hline & B & N.M. & S.M. & C & Pa & Y & T & Po & K & M \\
\hline Bonin Is. & - & & & & & & & & & & \\
N. Mariana Is. & 0.17 & - & & & & & & & & & \\
S. Mariana Is. & 0.13 & 0.83 & - & & & & & & & & \\
Caroline Is. & 0.13 & 0.67 & 0.29 & - & & & & & & & \\
$\quad$ Palau I. & 0.10 & 0.50 & 0.30 & - & - & & & & & \\
$\quad$ Yap I. & 0.00 & 0.33 & 0.29 & - & 0.71 & - & & & & \\
$\quad$ Truk I. & 0.00 & 0.50 & 0.50 & - & 0.67 & 0.67 & - & & & \\
$\quad$ Ponape I. & 0.20 & 0.60 & 0.60 & - & 0.80 & 0.60 & 0.60 & - & & \\
$\quad$ Kusaie I. & 0.00 & 0.75 & 0.75 & - & 0.50 & 0.50 & 0.75 & 0.75 & - & \\
Marshall Is. & 0.00 & 0.50 & 0.50 & 1.00 & 0.00 & 0.00 & 0.50 & 0.00 & 0.50 & - \\
\hline
\end{tabular}

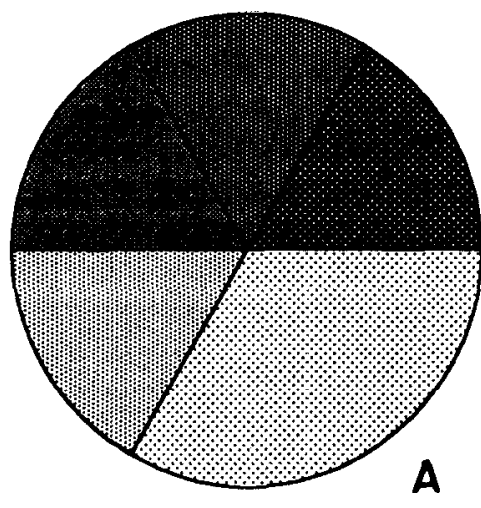

Northern Mariana Islands

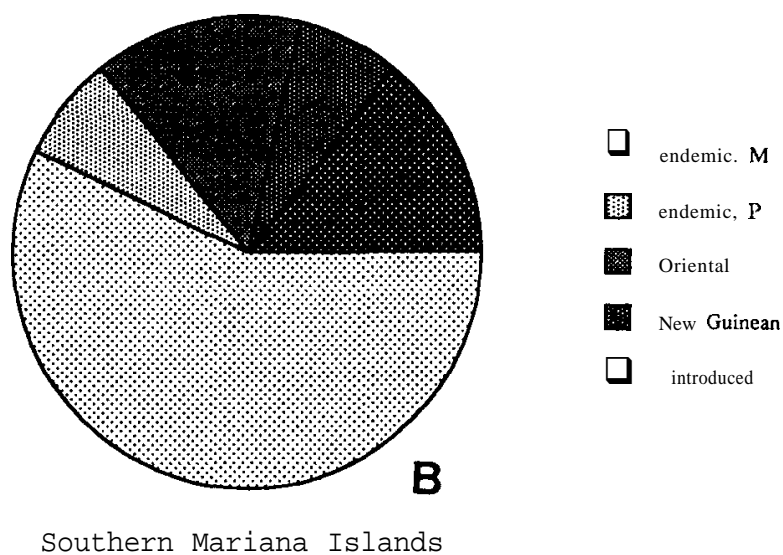

Southern Mariana Islands

Fig. 4. Proportion of the numbers of components for Northern (A) and Southern (B) Mariana Islands. Endemic, M: endemic to Mariana Is.; endemic, P: endemic to Pacific Is.

each pair of islands as follows: $c / b(a \geqq)$, where a is the number of species on $\mathrm{A}$ island, $b$ is that on $\mathrm{B}$ island and $\mathrm{c}$ is that in common. The table shows the Northern Marianas have the highest value (0.83) with the Southern Marianas, followed by Kusaie (0.75) and Carolines (0.67). The fauna of the Northern Marianas is strongly related to that of the Southern Marianas and is disharmonic in 
components. Only two species, Homalictus vexator and Heriades paganensis are endemic to the Northern Islands. Three species of Megachilidae are widely distributed in the Pacific Islands, including one originating from the Oriental Region and one from the New Guinean. Apis mellifera was introduced from Hawaii through the Southern Islands.

\section{ACKNOWLEDGEMENTS}

I am deeply indebted to Dr. S. Miyano of the Natural History Museum \& Institute, Chiba, for his giving me an opportunity of examining materials collected on the expedition. I am also thankful to Prof. K. Morimoto of Kyushu Univ. and Prof. Emeritus G. T. Riegel of Eastern Illinois Univ. for their reading the manuscript.

\section{REFERENCES}

Brindle, A., 1972. Dermaptera. Insects of Micronesia, B. P. Bishop Mus., 5: 97-171.

Cockerell, T. D. A., 1942. Insects of Guam - I. Hymenoptera. Bees of Guam. Halictine bees from Rota Islands. B. P. Bishop Mus. Bull., 172: 189.

Fennah, R. G., 1956. Homoptera: Fulgoroidea. Insects of Micronesia, B. P. Bishop Mus., 6: 39211.

Fullaway, 1913. Report on a collection of Hymenoptera made in Guam, Marianne Islands. Proc. Hawaii. Entomol. Soc., 2: 282-290.

Gressitt, J. L., T. C. Maa, I. M. Mackerras, S. Nakata, \& L. W. Quate, 1961. Problems in the zoogeography of Pacific and Antarctic insects. Pac. Insects Monogr., 2: 1-94.

Krombein, K. V., 1950. The Aculeate Hymenoptera of Micronesia II. Colletidae, Halictidae, Megachilidae, and Apidae. Proc. Hawaii. Entomol. Soc., 14: 101-142.

Townes, 1947. Rpt. 14, U.S. Comm. Co. Surv. Micronesia.

Yasumatsu, K., 1935. Notes on two Apoidea collected by Prof. Tohru Uchida on the Mariana and West Caroline Islands. Mushi, 8: 94-96.

$\longrightarrow, 1939$ a. Apoidea of Micronesia (Hymenoptera). Tenthredo, 2: 229-338, pls. 9-13. -, 1939b. Apoidea of Micronesia II. Ceratinidae. Tenthredo, 2: 344-347. ,1942..Apoidea of Micronesia. III. Records of the genera Megachile, Heriades, Ceratina and Prosopis. Tenthredo, 3: 335-348, pl. 